\title{
Illköğretim Matematik Öğretmenlerinin Denklem ve Eşitlik Konusundaki Pedagojik Alan Bilgilerinin Öğrenci Bileşeni Açısından Değerlendirilmesi
}

\author{
Hülya SERT ÇELIK, Ercan MASAL ${ }^{*}$ \\ Illköğretim Matematik Öğretmenlerinin Denklem ve \\ Eşitlik Konusundaki Pedagojik Alan Bilgilerinin Öğrenci \\ Bileşeni Açısından Değerlendirilmesi
}

Özet

Araştırmada öğretmenlerin eşitlik ve denklem konusuna yönelik pedagojik alan bilgilerini öğrenci bilgisi bileşeni açısından incelemek ve bu bileşene göre öğretmelerin geliştirdikleri çözüm önerilerini belirlemek amaçlanmıştır. Çalışma grubunu, Marmara Bölgesinde bir ilçedeki ortaokullardan amaçlı örnekleme yöntemi ile seçilen 10 ortaokulda 7. sınıflara ders vermekte olan 10 ilköğretim matematik öğretmeni oluşturmaktadır. Veriler, Eşitlik ve Denklem Konusundaki Öğrenci Bilgisi Bileşenine Yönelik Pedagojik Alan Bilgi Anketi (PABA) ile toplanmıştır. PABA' nin uygulandığı öğretmenler Ö1-Ö10 ile kodlanmış öğretmenlerden elde edilen veriler, öğrenci bilgisi bileşeni bağlamında incelenmiştir. Bu çalışma sonucunda, eşitlik ve denklem konusuna yönelik öğretmenlerin, öğrencilerin sahip olması gereken ön bilgiler, öğrencilerin sahip oldukları kavram yanılgıları ve öğrencilerin yaşadıkları öğrenme güçlükleri hakkında bilgi düzeylerinin yeterli olmadığı belirlenmiştir.

Anahtar Kelimeler: Pedagojik Alan Bilgisi, Denklem ve Eşitlik, Pedagojik Alan Bilgisi, Öğrenci Bilgisi Bileşeni.
Evaluation of Pedagogical Content Knowledge of Elementary Mathematics Teachers on Equation and Equality in Terms of Student Component

\section{Abstract}

In this research, it is aimed to examine the pedagogical content of the teachers about equality and equation in terms of the student information component and to determine the solution proposals developed by the teachers according to this component. The study group consisted of 10 elementary mathematics teachers who were teaching 7th grade students in 10 secondary schools which were chosen by purposeful sampling method from the secondary schools in a district in Marmara Region. The data were collected using the Pedagogical Field Knowledge about the Student Knowledge Component on Equality and Equation Questionnaire (PABA). The data obtained from the teachers who were coded by the teachers Ö1-Ö10 were studied in the context of the student information component. As a result of this study, it was determined that the level of knowledge of the teachers about equality and equation, the pre-knowledge students should have, the students 'misconceptions and the students' learning difficulties were insufficient.

Key Words: Pedagogical Content Knowledge, Equation and Equality, Student Knowledge.

\section{Giriş}

Shulman (1986) eğitim psikolojisinin genel perspektifinin ötesine geçerek, öğrenme ve öğretim alanına özgü süreçlerin önemini vurguladığı araştırmasında, öğretmenlerin sahip olması gereken bilgileri üç temel boyutta ele almıştır. Bu boyutlar alan bilgisi, pedagojik alan bilgisi ve genel pedagojik bilgidir (Shulman, 1986; Baumert, Kunter, Blum, Voss,

*Hülya SERT ÇELiK, Öğretmen., İçmeler İnayet Coşkun Kodak-Kamil Acarer Ortaokulu, hlyasert@gmail.com, ORCID ID orcid.org/ 0000-0002-5021-7449, Ercan MASAL Dr. Öğr. Üyesi., Sakarya Üniversitesi Eğitim Fakültesi, Matematik Eğitimi Bilim Dalı, emasal@sakarya.edu.tr, ORCID ID orcid.org/ 0000-0001-8351-7248 
Jordan ve Tsai, 2010). Pek çok araştırmacı, bu temel bileşenlere yaptıkları eklemelerle öğretmenlerin sahip olması gereken bilgileri daha ayrıntılı tanımlamışlardır. Bu tanımlanan modellerde odak, öğretmenlerin konu ile ilgili alan bilgisi ve pedagojik alan bilgisine yöneliktir ( An, Kulm ve Wu, 2004; Ball, Thames ve Phelps, 2008; Grossman, 1990; Magnusson, Krajcik ve Borko, 1999; Park ve Oliver, 2008; Tamir, 1988).

Alan bilgisi, öğretmenlerin konu hakkındaki bilgisini temsil etmektedir. Alan bilgisi için Shulman (1986) vurguyu, öğretmenin konuyu sebep-sonuç ilişkisi içerisinde açıklayabilecek şekilde bilmesine, okulda öğretilen konuların derinlemesine anlaşılmasına yapmaktadır. Pedagojik alan bilgisi ise, konuların öğrencilere erişilebilir hale getirilmesi için öğretmenlerin sahip olması gereken bilgidir. Pedagojik alan bilgisinin iki temel yönü vardır. Bunlar öğrencilerin, konuya özgü kavram-kavram yanılgıları hakkındaki bilgileri ve konuya özel öğretim stratejileri-temsilleri hakkındaki bilgileridir (Ball vd., 2008; Borko ve Putnam, 1996; Park ve Oliver, 2008; Shulman, 1986).

Öğretim ve öğretmen eğitimi ile ilgili yapılan araştırmalarda, alan bilgisi ve pedagojik alan bilgisinin öğrenme ve öğretme süreçlerinde olumlu etkileri olduğu görülmektedir. Örneğin, genel ve alana özgü pedagojik bilginin, öğrencilerin öğrenme ve motivasyon gelişimini etkileyen öğretim kalitesinin önemli belirleyicileri olduğu konusunda ortak bir anlayış vardır (Bransford, Darling-Hammon ve LePage, 2005; Bransford vd.,2005; Grossman ve McDonald, 2008; Grossman ve Schoenfeld, 2005; Hiebert vd., 2007; Munby, Russell ve Martin, 2001; Reynolds, 1989). Alan bilgisi ve pedagojik alan bilgisi, öğretmenlerde öğretimi ve öğrencilerde de öğrenmeyi olumlu etkilemektedir (Baumert vd., 2010; Hill, Rowan ve Ball, 2005; Grossman, 1995; Sherin, 1996; Shulman, 1987).

Pedagojik alan bilgisinin çıkış noktasına baktığımızda; Shulman (1987), Grossman (1990), Tamir (1988), Magnusson vd. (1999), çalışmaları karşımıza çıkmaktadır. Grossman'ın (1990) ve Tamir'in (1988) çalışmalarına dayandırılarak Magnusson vd. (1999) tarafından geliştirilen pedagojik alan bilgisi modeli, fen öğretimi için öğretmenlerin sahip olması gereken bilgi türlerine yönelik olarak son yıllarda öne çıkan ve farklı disiplinlerde de kullanılan kapsamlı bir model olarak kabul edilmektedir. Bu model; Fen için Amaçlar Bilgisi, Program Bilgisi, Öğrencilerin Anlama Bilgisi, Öğretim Stratejileri Bilgisi ve Değerlendirme Bilgisi şeklinde 5 ana başlıkta toplanmaktadır. Modelde fen öğretiminin amaç ve hedeflerine yönelik bilgi bileşeni modelin üst kısmında ve diğer bileşenlerin tamamını kapsayan konumda yer almaktadır. Öğrencilerin Anlama Bilgisi bileşeni ise Öğrenme için Gerek Duyulan Gereklilikler (ön bilgi ve yeni bilgiler arasında bağlantı kurma, öğrencilerin kavram yanılgılarını, hatalarını belirleyebilme) ve Öğrenme Zorlukları (konuya göre yaşanan anlama güçlüklerini belirleme) şeklinde iki alt bileşen olarak ele alınmaktadır.

Shulman (1987) öncülüğünde başlayan ve geliştirilerek yenilenen Pedagojik Alan Bilgisi ile ilgili başlıca modeller incelendiğinde öğrenci bilgisinin, pedagojik alan bilgisini oluş- 
turan bir alt bileşen olarak varsayıldığı görülmektedir. Öğrenci bilgisi; öğrencilerin öğrenecekleri konuyla ilgili sahip olmaları gereken ön bilgileri, yaşadıkları anlama güçlüklerini, sahip oldukları kavram yanılgılarını ve bu yanılgıları doğuran nedenlerin öğretmen veya öğretmen adayları tarafından belirlenmesine yönelik bilgi olarak tanımlanmaktadır (Ball ve Bass, 2000; Sert Çelik ve Masal, 2018; Magnusson, Krajcik ve Borko, 1999; Shulman, 1987).

Türkiye'de matematik öğretmen adayları üzerinde yapılan araştırmaların, öğretmen adaylarının aldıkları öğretim yöntem derslerinin pedagojik alan bilgilerine etkisini ve pedagojik alan bilgilerini seçilmiş konularda irdeleyen çalışmalar oldukları görülmektedir. Seviş (2008) matematik öğretimi yöntemleri dersinin ilköğretim matematik öğretmen adaylarının matematik öğretimine yönelik alan bilgilerine etkisini araştırdığı çalışmasında öğretmen adaylarının pedagojik alan bilgilerini geliştirmede yöntem derslerinin olumlu rolünü vurgulamaktadır. Baki (2012) de ders imecesi uygulamalarının öğretmen adaylarının matematiği öğretme bilgisi ve bunu oluşturan alt boyutlarına etkisini incelediği çalışmasında, ders imecesinin öğrenci ön bilgisini dikkate alma ve buna bağlı olarak dersi planlamada önemli derecede katkı sağladığını ortaya koymaktadır. Bileşke ve ters fonksiyonlar konusu ile ilgili (Karahasan, 2010), kesirler konusu ile ilgili (Eroğlu, 2012), denklem, eşitlik ve değişken kavramlarıyla ilgili öğrencilerin zorluklarını tahmin etme ve kavram yanılgılarını belirleyebilme becerilerini tespit etme ile ilgili (Tanışlı ve Köse, 2013), geometrik cisimler konusu (Gökkurt, Şahin, Soylu ve Doğan, 2015) ile ilgili olarak yapılan çalışmalarda öğretmen adaylarının pedagojik alan bilgilerinin yeterli seviyede olmadıkları ifade edilmektedir. Türkiye'de Matematik öğretmenleriyle yapılan bazı çalışmalarda da yine öğretmenlerin pedagojik alan bilgilerinin eksik olduğu ifade edilmektedir (Bingölbali, 2010; Gökkurt ve Soylu, 2016; Kutluk, 2011). Bingölbali (2010) matematik dersi etkinlik uygulamaları esnasında gözlemlenen öğrenci zorluklarının nedenlerini tespit etmek ve bu zorluklar karşısındaki öğretmen müdahale türlerini belirlemeyi amaçladığı çalışmasında, öğrenci zorluklarının meydana gelmesinde öğrencilerden kaynaklı nedenlerin yanında öğretmenlerin de önemli derecede rol oynadığını ifade etmektedir. İlköğretim matematik öğretmenlerinin öğrenci güçlüklerini gidermeye yönelik bilgileri eksik olup diğer taraftan bu durumu yeterince önemsememektedirler (Kutluk 2011). Gökkurt ve Soylu (2016) koni konusuna ilişkin öğretmenlerin pedagojik alan bilgilerinin eksik veya yanlış olduğunu belirtmektedirler.

Matematiğin diğer konularında olduğu gibi, öğrencilerin cebir konusunda öğrenme zorlukları yaşadığını gerek yurtiçi gerekse yurtdışında yapılan çalışmalar ortaya koymuştur (Akkaya ve Durmuş, 2006; Asquith vd.,2007; Dede, Yalın ve Argün, 2002; Gürbüz ve Akkan, 2008; Hoch ve Dreyfus, 2004, Jacobs vd., 2007; Stacey ve Macgregor, 1997; Pope ve Sharma, 2001; Wagner, 1983; Yaman, Toluk ve Olkun, 2003). Dede ve Argün (2003) cebir öğretiminde öğrenci başarısını etkileyen en önemli faktörün öğretmenlerin öğretim esnasında öğrencilerin yaşayabilecekleri zorlukları bilip, bunların üstesinden gelmek için geliş- 
tirdiği çözüm önerileri olduğuna vurgu yapmaktadırlar. Wanjala ve Orton (1996) ise, öğretmenlerin bir kısmının öğrencilerin önceden hangi hataları yapabileceklerini belirlemede başarılı olduklarını, bir kısmının ise verilen öğrenci yanıtlarına ilgisiz öneriler sunduklarını ve diğerlerinin de herhangi bir fikir ileri süremediklerini ifade etmektedirler. Türnüklü (2005), matematik öğretmenlerinin konu öğretimini gerçekleştirebilmeleri için güçlü bir matematiksel bilgiye sahip olmaları gerektiğini fakat bu öğretimin pedagojik alan bilgisi kullanılmadan yeterli seviyeye ulaşmayacağını belirtmiştir.

Cebirin öğrenciler için anlam ifade etmesinin, ancak öğretmenlerin cebiri anlaşılabilir kılması ile mümkün olabileceği düşünülmektedir (Wanjala ve Orton, 1996). Cebir konularından birisi olan eşitlik ve denklem, öğrencinin hayatı boyunca karşısına çıkan ve temelleri ilköğretimden itibaren atılmaya başlanan, matematiğin temel konularındandır. Günlük hayatta sıklıkla kullanılabilir olan, hem cebir hem matematik alanında hem de diğer (fizik, kimya vb.) bilim dallarında geniş kullanım ve uygulama alanı olan eşitlik ve denklem konusunun kavram yanılgılarından arındırılmış olarak öğretilmesi önemlidir. Türkiye'de bu konuda yapılan bazı çalışmalar genel olarak öğrencilerin sıkça yaptıkları bazı yanlışları kavram yanılgısı veya yanlış/yetersiz (kavramsal veya işlemsel) bilgi olarak belirtilmektedir (Erbaş, Çetinkaya ve Ersoy, 2009). Dede, Yalın ve Argün (2002) ortaokul son sınıf öğrencilerinin değişken kavramının öğrenimine ilişkin yaptıkları yanlış anlama ve hataları değerlendirmeyi hedefledikleri çalışmalarının sonucunda, öğrencilerin değişken kavramını anlamlandıramadıklarını ve özellikle de öğrencilerin değişken kavramı yardımıyla genelleme ve soyutlama yapamadıklarını ortaya koymakta, değişken kavramının öğretimine başlanmadan önce, öğrencilerin ön öğrenmelerinin (aritmetik işlem bilgisi hakkındaki) tespit edilip varsa eksikliklerinin giderilmesi gerektiğine vurgu yapmaktadırlar. Ertekin (2002), denklem öğretiminde görülen hatalara çözüm önerisi olarak, öğrencilere denklem çözümüyle alakalı matematiğin diğer konuların tekrar edilmesi (ön bilgi yeni bilgi arasında bağ kurma), işlem yapma, öğretmenlere ise öğrencilerin sahip oldukları hata ve kavram yanılgılarını ortadan kaldırmaya yönelik çalışmalar düzenlemesini önermektedir. Bu bağlamda, bu araştırmada öğretmenlerin eşitlik ve denklemler konusuna yönelik pedagojik alan bilgilerini öğrenci bilgisi bileşeni (öğrencilerin a) ön bilgi ve yeni bilgiler arasında bağlantı kurmada yaşadıkları güçlükleri belirleyebilme, b) yaşadıkları kavram yanılgılarını belirleyebilme ve c) konuya göre yaşadıkları anlama güçlüklerini saptayabilme becerileri) açısından incelemek ve bu bileşene göre öğretmelerin geliştirdikleri çözüm önerilerini belirlemek amaçlanmıştır.

\section{Yöntem}

İlköğretim matematik öğretmenlerinin pedagojik alan bilgilerinin öğrenci bilgisi bileşeni yönünden ele alındığı bu araştırmada nitel araştırma yaklaşımlarından durum çalışması benimsenmiştir. Araştırmada, ilköğretim matematik öğretmenlerinin, öğrencilerin eşitlik ve denklem konusunda yaşayabilecekleri güçlükler hakkındaki bilgilerinin, bu güç- 
lükleri ortadan kaldırmak ya da hiç yaşamamaları için alabilecekleri tedbirlerin ve kullanabilecekleri yöntemlerin belirlenmesi birer durum olarak nitelendirilerek, bu durumlara ilişkin "nasıl” ve "niçin" sorularına cevap aranmıştır. (Büyüköztürk, Kılıç Çakmak, Akgün, Karadeniz ve Demirel, 2008; Yin, 2003).

\subsection{Katılımcılar}

Araştırmanın çalışma grubunu, Marmara Bölgesinde yer alan bir ilçedeki ortaokullardan seçkisiz olmayan örnekleme yöntemi ile seçilen, 2016-2017 Eğitim öğretim yılında 7. sınıflara ders veren 10 ortaokuldan 4 kadın, 6 erkek öğretmen olmak üzere 10 ilköğretim matematik öğretmeni oluşturmaktadır. Öğretmenlerin mesleki deneyimi, 0-5 yıl arasında 3, 6-10 yıl arsında 4, 11 yıl ve üzeri 3 öğretmen şeklindedir. Araştırmanın yürütülmesi için belirlenen okullar ve öğretmenler, amaçlı örnekleme yöntemlerinden kolay ulaşılabilir durum örneklemesine göre seçilmiştir. Kolay ulaşılabilir durum örneklemesi, araştırmacıya hız ve pratiklik kazandırmaktadır. Araştırmacı bu yöntemde, yakın olan ve erişimi kolay olan bir durumu seçmektedir (Yıldırım ve Şimşek, 2008).

\subsection{Veri Toplama Araçları}

İlköğretim matematik öğretmenlerinin eşitlik ve denklem konusundaki pedagojik alan bilgilerini öğrenci bilgisi bileşeni açısından inceleyebilmek için veriler, araştırmacılar tarafından geliştirilen Eşitlik ve Denklem Konusundaki Öğrenci Bilgisi Bileşenine Yönelik Pedagojik Alan Bilgi Anketi (PABA) ile toplanmıştır.

Ankette yazılı olarak katılımcılara Ortaokul Matematik Öğretim Programında (2013) yer alan 7.Sınıf Eşitlik ve Denklem Konusu Kazanımları hatırlatılmakta, sırasıyla öğrenci bilgisi bileşenini oluşturan, ön bilgi-yeni bilgi, kavram yanılgıları ve anlama güçlükleri ile ilgili sorular yer almaktadır.

Ankette yazılı olarak katılımcılara Ortaokul Matematik Öğretim Programında (2013) yer alan 7.Sınıf Eşitlik ve Denklem Konusu Kazanımları hatırlatılmakta, sırasıyla öğrenci bilgisi bileşenini oluşturan, ön bilgi-yeni bilgi, kavram yanılgıları ve anlama güçlükleri ile ilgili sorular yer almaktadır. PABA, Sert Çelik ve Masal (2018) tarafından geliştirilen ve uygulanan Denklem ve Eşitlik Konusundaki Öğrenci Bilgisi Belirleme Testi (ÖBBT) sonuçlarından elde edilen 24 kod, 11 kategori ve 3 tema dikkate alınarak hazırlanmıştır. ÖBBT de ön bilgi ve yeni bilgiler arasında bağlantı kurma (YB), kavram yanılgıları (KY) ve yaşanan anlama güçlükleri (AG) şeklinde üç tema belirlenmiştir. Bu temaları oluşturan kategoriler, kategorileri oluşturan kodlar ve kodların tespit edildiği soruların cevaplarından duruma uygun sık tekrarlanmış öğrenci cevapları (A2a,A2b,A2c,B2a,B2b,B2c, C2a,C2b,C2c) PABA da kullanılmıştır. Bu soruların elde edildiği öğrenciler, verilerin toplandığı dönemde PABA nın uygulandığı öğretmenlerin kendi öğrencileridirler.

$P A B A, A, B$ ve $C$ şeklinde üç bölümden ve her bölüm üç sorudan meydana gelmektedir. Bölümlerin ilk sorusunu araştırmaya katılan öğretmenlerin kendi deneyim ve bilgileri- 
Hülya SERT ÇELIK | Ercan MASAL

ne dayanarak cevaplanması istenmektedir. 7.Sınıf Eşitlik ve Denklem Konusu Kazanımları için öğretmenlerin, öğrencilerinden sahip olmasını bekledikleri ön bilgileri (A1), öğrencilerinin sahip oldukları kavram yanılgıları (B1) ve öğrencilerinin yaşadıkları öğrenme güçlüklerini (C1) ifade etmeleri istenmektedir. İkinci olarak katılımcılardan her bir şık için öğrencilerin verdiği cevaplar üzerinden ön bilgi (A2a,A2b,A2c), kavram yanılgıları (B2a,B2b,B2c) ve anlama güçlükleri $(\mathrm{C} 2 \mathrm{a}, \mathrm{C} 2 \mathrm{~b}, \mathrm{C} 2 \mathrm{c})$ açısından görüşlerini belirtmeleri istenmektedir. Son bölümde ise ikinci sorular ile kendilerine gösterilen öğrencilerin en sık tekrarladıkları, ön bilgiler ve yeni bilgiler arasında bağlantı kurmada yaşadıkları güçlükleri (A3), yaşadıkları kavram yanılgılarını (B3) ve anlama güçlüklerini gidermek için çözüm önerilerini (C3) ifade etmeleri katılımcılardan istenmektedir.

Matematik eğitiminde uzman iki akademisyenin görüşü alındıktan sonra, iki ortaokul matematik öğretmeni ile pilot uygulaması yapılarak ve bir dil uzmanının görüşleri doğrultusunda PABA' ya son şekli verilmiştir.

\subsection{Verilerin Analizi}

PABA' nin uygulandığı on öğretmen sırasıyla Ö1- Ö10 ile kodlanmış öğretmenlerden elde edilen veriler öncelikle transkript edilerek, ardından araştırmacılar tarafından birbirlerinden bağımsız olarak, öğretmenlerin eşitlik ve denklem konusuna ilişkin gördükleri anlama güçlükleri, kavram yanılgıları ve ön bilgi-yeni bilgi bağlamında incelenmiş ve öğretmenlerin bu bileşenlere yönelik farkındalıkları görülmeye çalışıımıştır. Ayrıca yaşanan sıkıntılara çözüm bulma konusundaki yöntem ve stratejileri belirlenmeye çalışılmıştır. Verilerin analizinde betimsel analiz tekniği kullanılmış olup veriler çalışmaya doğrudan aktarılmıştır.

\section{Bulgular}

\section{1. Öğretmenlerin Öğrenci Bilgisi Bileşeni Hakkındaki Öngörüleri}

Katılımcılara, Ortaokul Matematik Öğretim Programında (2013) yer alan 7.Sınıf Eşitlik ve Denklem Konusu Kazanımları hatırlatılarak, deneyimlerine dayanarak bu kazanımlar için öğrencilerinin sahip olmasını bekledikleri ön bilgileri, öğrencilerinin sahip oldukları kavram yanılgıları ve öğrencilerinin yaşadıkları öğrenme güçlüklerini ifade etmeleri istenmiştir ve bulgular aşağıda sıralanmıştır:

\subsubsection{PABA A1 öğretmen görüşleri ve bulgular}

Eşitlik ve denklem konusunun öğrenilebilmesi için öğrencilerin sahip olmasını bekledikleri ön bilgiler ile ilgili olarak,

Ö1, Ö4 ve Ö5 dışındaki öğretmenler cebirsel ifadelerin bilinmesinin gerekliliği konusunda ortak görüş belirtmektedirler. 
- Bilinen ve bilinmeyen kavramını bilmesi gerekiyor. Bilinmeyenlerin hangi işaret veya harflerle gösterildiğini... (Ö1)

- Değişken ve sabit ifadelerin ne anlama geldiğini bilmelidir. Ifadelerin ön kısmında (sol taraf) işaretlerinin olduğunun, bu işaretlerin sayı doğrusunda ne ifade ettiğini bilmelidir. Soruda istenenin ne ile ifade ettiğini buna bağlı olarak bir denklem iskeleti oluşturmayı bilmelidir, (Ö4)

- Matematiksel temel 4 işlem becerilerine sahip olmalıdırlar. Eşitlik kavramını bilmelidirler. Toplamanın tersinin çıkarma, çarpmanın tersinin bölme olduğunu bilmelidirler, (Ö5)

Ö1 bilinen ve bilinmeyen terimlerine vurgu yapmasına rağmen bu terimler MEB Matematik Dersi Öğretim Programı (1-8) de Eşitlik ve Denklem konusunda ilk kez geçmektedir. Ö4 dolaylı olarak cebirsel ifadelere vurgu yaparken, Ö5 ise temel dört işlem becerisine ve eşitlik kavramının bilinmesinin ön bilgi için yeterli olduğunu ifade etmektedirler.

Öğrencilerin; bilinmeyen kelimesinin matematikte karşılı̆ı̆na ve cebirsel ifadeler konusuna hakim olması gerekir. Eşitlik, denge(günlük hayattaki örnekleri) ne anlama gelir ve ne gibi durumlarda karşımıza çıkar sorularının cevabını bulması gerekir.(Ö8)

Ö8 her ne kadar cebirsel ifadelerin önemine vurgu yapmış olsa da bilinmeyen ve denge gibi Eşitlik ve Denklem konusunun kazanımlarını ön bilgi olarak görmesi dikkate değerdir.

- Cebirsel ifadeleri kavramasını, cebirsel ifadelerle toplama çıkarma yapabilmesini, işlem önceliğini bilmesini, parantezin kullanımını, tam sayıları tanımasını ve tam sayılarda dört işlem yapabilmesini, küme kavramını bilmesini beklerim. (Ö7)

- Bir duruma uygun cebirsel ifade yazabilme kazanımını bilmeli, tamsayılarda çarpma ve bölme işlemini yapar kazanımını bilmeli, cebirsel ifadelerde toplama ve çıkarma işlemi yapar kazanımını bilmeli, bir doğal sayıyla bir cebirsel ifadeyi çarpar kazanımını bilmeli. (Ög)

Ö1, Ö2, Ö3, Ö5, Ö7, Ö9 ve Ö10 ise tam sayılarla işlem yapabilme becerisine sahip olmanın gerekliliğini belirtmektedirler.

\subsubsection{PABA B1 öğretmen görüşleri ve bulgular}

Eşitlik ve denklem konusunda öğrencilerin sahip oldukları kavram yanılgıları ile ilgili olarak, aritmetik işlemleri yanlış şekilde cebire genelleştirmeleri, ters işlem hatası, toplananın yer değiştirmesi hatası, değişkenlerden önceki - işaretinin ihmal edilmesi ve tanıdık olmayanı görmezden gelmenin sıklıkla karşılaşılan kavram yanılgıları olduğu alan yazından anlaşılmaktadır (Kieran, 1992; Ertekin, 2002; Akkaya ve Durmuş, 2006; Oktaç, 2010; Çavuş Erdem, 2013). 
Hülya SERT ÇELIK | Ercan MASAL

Ö2, Ö5, Ö8 ve Ö10’nun eşitlik ve denklem konusuna ait kavram yanılgılarına uygun örnekler vermek yerine matematik dersinin genel özelliklerinden bahsetmektedirler.

Öğrencilere herhangi bir kazanım öğretilmeden önce gerekli terimlerin iyice kavratılması gerekiyor. (Ö2)

- Matematik temelleri sağlam olmadığından dolayı çoğu soruda ne sorulduğunu anlamıorlar.(Ö5)

Ö1, Ö3, Ö7 ve Ö9 ise tamsayılarda işlemler ve cebirsel ifadelerin sağlam temellendirilmesinin gerekliliğine vurgu yapmaktadırlar.

- Denklem konusu kendi içerisinde cebirsel ifadeler, tam sayılar, işlem önceliği, dağılma özelliği konularını içerdiği için önceki bilgi ile yeni bilgi arasında bağlantı kurmayıp, yeni konuya odaklandıklarından dolayı bu konuyu öğrenmekte güçlük çekip, kavramları karıştırmaktadırlar.(Ö3)

- Eşitliğin korunumunu, kesirlerle ilgili cebirsel ifadeleri ve tam sayılarda toplama çıkarma işlemlerini kavrayamadıklarını düşünüyorum. (Ö7)

Ö4 ve Ö6 ise tamsayılarda işaret kavramının önemini ifade etmektedirler.

- Öğrenciler, işaretlerin ne anlama geldiği tam olarak bilmediği için, örneğin 2 ile -2 arasında onlar için bir fark yok. Hatta (+) pozitiflik özel olarak anlatılmadığı için yokmuş gibi davranıyorlar. O yüzden sonucu işaretleriyle değil de sayısal değeri ile bulmak yeterli oluyor. İsteneni sadece harfle ifade etmek yerine başka bir sembolle ifade edilmesi gerektiğini bilmiyorlar.(Ö4)

- Bu durumlara ders işlerken de şahit oluyorum. Özellikle negatif sayılarda sayının işaretini önemsemiyorlar, işlem yaparken dikkate almıyorlar. Cebirsel ifadeleri anlamakta güçlük çekiyorlar. (Ö6)

\subsubsection{PABA C1 öğretmen görüşleri ve bulgular}

Aritmetik işlemlerde sayı yerine sembol kullanarak değişik ve yalın çözüm yollarının ortaya konulması cebirin işlevini açıklamakta (Akkaya ve Durmuş, 2006) ve cebir temel olarak gerçek hayatla ilişkisi az olan sembollerle işlemleri ve yapay uygulamaları içermektedir. Bu sebeple öğrenciler öğrenme yaşantılarını anlamlandırmada ve gerçeğe uygunluğunu değerlendirmede sıkıntı yaşayabilmekte, işlem yapmak için kullandıkları yöntemler ve sayı sisteminin yapısını değişkenlere genellemede dolayısıyla, verilen gerçek hayat durumlarına uygun birinci dereceden bir bilinmeyenli denklem kurma ve eşitliğin korunumu ilkesinde sıklıkla anlama güçlüğü yaşamaktadırlar (Çakmak Gürel ve Okur 2017; Behr, Erlwenger ve Nichols, 1980; Carpenter ve Levi, 2000; Falkner, Levi, ve Carpenter, 1999) Eşitlik ve denklem konusunda öğrencilerin karşılaşabilecekleri öğrenme güçlüklerini ifade etmeleri istenen öğretmenler, 
Ö1, Ö5, Ö7 ve Ö9 öğrencilerin probleme uygun denklem kurmada anlama güçlüğü yaşadıklarını ifade etmektedirler ve Ö9 bu durumun nedeni olarak öğrencilerin önceki hatalı öğrenmelerini göstermektedir.

- En çok denklem kurmada problem yaşıyorlar.(Ö1)

- Denklemler karmaşıklaştıkça ön bilgileri daha yetersiz hale geliyor, tam sayılarla işlemler gerektiğinde zorlanıyorlar. Cebirsel ifadelerde toplama çıkarmakta zorlanıyorlar. Benzer terimleri aynı tarafa geçirirken güçlük yaşıyorlar. Problemlerde denklem kurmakta zorlanıyorlar. Içinde tamsayılarda işlem gerektiren ve kesir olan denklemlerin çözümünde zorlanıyorlar. (Ö7)

- Denklem çözme konusunda 4 işlem konusunda eksiği olanlar çok zorlanıyorlar. Özellikle problem çözme konusunda okuduğunu anlayıp yorumlayabilme ve denklem yazma konusunda sıkıntı yaşıyoruz. Çeşitli vesilelerle yaşanan deneyimlerinden (önceki yanlış öğrenmeler). (Ö9)

Ö3 ve Ö5 eşitlik ve denklem konusunun soyut yapısından kaynaklı öğrencilerin anlama güçlüğü yaşadıklarını, somut örneklerle anlatmanın konunun öğrenilmesi açısından önemli olduğuna vurgu yapmaktadırlar. Ö5 ek olarak, farklı yöntemlerle denklem çözmeyi gösterdikten sonra öğrencilerinden kendileri için anlaşılır olanı seçmelerini istemesine rağmen istenen başarıyı sağlayamadığını konunun lise müfredatına uygun olduğunu ifade etmektedir.

- Öğrenciler öncelikle harfli ifadelerin kendi aralarında sayı gibi toplanıp çıkarılamayacağını, çarpılıp bölünemeyeceğini düşünmektedir. Öğrencilere bu konu soyut olarak anlatıldığında öğrenme güçlüğü yaşıyorlar. Eşitliği, eşit kollu terazi olarak düşünmeliyiz denince daha rahat anlayabiliyorlar.(Ö3)

- En başta somutlaştırılması zor oluyor, zaman alıyor. iki üç farklı yollarla denklem çözüp hangisini isterlerse onu seçebilirler diye seçenek sunuyorum. Ama yine de istenen başarı sağlanamıyor. Özellikle denklem kurma problemlerinde epey zorluk çekiyoruz ve bu konun lise müfredatına uygun olduğunu düşünüyorum. (Ö5)

Ö2, Ö3, Ö4, Ö6 ve Ö8 cebirsel ifadeler ve denklemlerle ilgili temel kavramların öğretilmesi gerekliliğini ifade ederek, öğrencilerin anlama güçlüğünün negatif tamsayılarda ki işlemlerde yaşanan güçlüklerden kaynaklı olduğunu belirtmektedirler.

- Aslında tam anlamıyla negatif sayıların varlığı öğrencilerin kafasını karıştırıyor. Iki pozitif tamsayıyı toplarken sıkıntı yaşanmazken negatif sayı devreye girdiğinde problem yaşanıyor. Ve bu problem denklemlerde de öğrenciyi zorluyor.(Ö8)

- Cebirsel ifadelerle, özellikle toplama, çıkarma ve çarpma işlemlerinde zorlanıyorlar, o sebeple denklem çözerken de hata yapıyorlar.(Ö6) 
Hülya SERT ÇELIK | Ercan MASAL

Ö10 sadece öğrencilerin bu sınıf seviyesi için hala somut dönemde kalıp soyut döneme geçemediklerini belirtmiş olup yaşanan güçlüklerden bahsetmektedir.

Öğrencilerin soyut kavramları öğrenecek kadar yeterli olduklarını düşünmüyorum.(Ö10)

\section{2. Öğretmenlerin Öğrenci Bilgisi Bileşeni Hakkındaki Tespitleri}

Sert Çelik ve Masal (2018) tarafından geliştirilen ve uygulanan Denklem ve Eşitlik Konusundaki Öğrenci Bilgisi Belirleme Testi (ÖBBT) sonuçları dikkate alınarak, öğrenci bilgisi bileşenini en iyi açıkladığı görülen sorulardan, her bir bölüm için üçer soru ve verilen duruma uygun sık tekrarlanmış öğrenci cevapları seçilmiştir. Katılımcılardan her bir şık için öğrencilerin verdiği cevaplar hakkında ön bilgi (A2a,A2b,A2c) kavram yanılgıları (B2a,B2b,B2c) ve anlama güçlükleri $(C 2 a, C 2 b, C 2 c)$ açısından görüşlerini belirtmeleri istenmiştir ve bulgular aşağıda sıralanmıştır.

\subsection{1. Öğretmenlerin Öğrencilerin Ön Bilgi-Yeni Bilgi Hakkındaki Tespitleri}

\subsubsection{PABA A2a öğretmen görüşleri ve bulgular}

$5(y-2)=-40$ sorusunu öğrencilerin bir kısmının $y=6$ olarak cevapladıkları ve öğrencileri bu cevaba götüren ön bilgi eksikliğinin ne olduğuna ilişkin görüşleri sorulduğunda;

Ö5 hariç tüm öğretmenler, tamsayılarda işlemler konusunda sıkıntı yaşandığı eksik öğrenilen konunun ise tamsayılarda bölme işlemi olduğu yönünde görüş belirtmektedirler.

Negatif ve pozitif kavramını tam olarak anlamamışlar. (-)'nin (+)'ya bölümünü kavrayamamışlar ve tamsayılarda, toplama ve çıkarmada hala eksikler var.(Ö1)

- Negatif tam sayıların pozitif tamsayıya bölünmesi işleminde işaret hatası yapılmıştır. Eksik öğrenilen konu tamsayılarla bölme işlemi.(Ö6)

- Tam sayılarda çarpma ve bölme işleminde eksikliğini olduğunu düşünüyorum.(Ö9)

Ö5 ise öğrencinin işlem basamağını bir yere kadar ilerletip sonra yapılan hatanın dikkatsizlikten kaynaklandığını söylemektedir. Bu durumda bunun bir hata olduğunu düşünmeyip sadece bir soru bazında yapılan dikkatsizlik olduğunu düşünmekte, geçici bir hata olduğunu varsaymaktadır.

Öğrenciler her iki tarafı 5'e bölüp y-2=8 değerine ulaşmışlardır. Bir kısmı aceleci davranıp 8,2 ve eksi ifadelerini gördüğü için çıkarmış olabilir. (Ö5) 


\subsubsection{PABA $A 2 b$ öğretmen görüşleri ve bulgular}

Bir sınıftaki öğrencilerin 2/5' si erkek ise kız ve erkek öğrenci sayısının matematiksel ifadelerini yazınız sorusuna öğrencilerin yaklaşık yarısının $3 / 5$ kız, 2/5 erkek şeklinde cevapladıkları ve öğrencileri bu cevaba götüren ön bilgi eksikliğinin ne olduğuna ilişkin görüşleri sorulduğunda, Ö1 hariç diğer tüm öğretmenler görüş bildirmişlerdir.

Ö5, Ö8 ve Ö9 verilen cevabın doğru olduğunu belirtmektedirler (soruda istenen matematiksel ifade yazın sorusuna karşılık yine soruda bilinen oranı yazmalarını doğru olarak nitelendirmektedirler). Ö9 matematiksel ifadeden kastın oran olduğu düşünülürse verilen cevabın doğru olduğunu yoksa sınıf mevcudu verilmeden istenenlerin bilinemeyeceğini yani sorunun hatalı olduğunu dile getirmektedir.

- Bu soruda öğrencilerin matematiksel ifadeden ne kast ettiğini anlamayıp, düz mantık düşündüklerini ve 2/5'i erkekse 3/5'i kızdır. Bu da bir matematiksel ifadedir diye düşündüklerini tahmin ediyorum. (Ö5)

- Verilen cevap doğrudur. Öğrenciler sınıfın kız ve erkek öğrenci sayısını oranlayarak söylemiştir. Bütünlük kavramını anladıkları da söylenebilir. (Ö8)

Ö3, Ö6 ve Ö10 oran konusunun tam anlaşılmadığını ve yeni öğrenilen konuyla ilişkilendiremediklerine, Ö2,Ö4 ve Ö7 ise cebirsel ifadelere vurgu yapmaktadırlar, tır. (Ö6)

- Oran konusu tam anlaşılmamış, cebirsel ifadelerin yazımı anlaşılmamış-

- Soruyu tam olarak anlamadıklarını ve denklem konusu ile oran konusunu ilişkilendiremediğini düşünüyorum.(Ö10)

- Cebirsel ifadeler konusunda eksiklikler var. (Ö2)

- Bu örnekte öğrenciler verilen sözel ifadeyi cebirsel olarak ifade edememiş, özellikle ifadede kesir varsa daha da zorlaşıyor. Özellikle bütünün kesir kadarını cebirsel olarak ifade etme öğrenciler için zor bir kazanım. (Ö7)

\subsubsection{3. $P A B A A 2 c$ öğretmen görüşleri ve bulgular}

$38+5=45-$ ? sorusunu öğrencilerin bir kısmının ? =-2 şeklinde cevapladıkları ve öğrencileri bu cevaba götüren ön bilgi eksikliğinin ne olduğuna ilişkin görüşleri sorulduğunda,

Ö5 ve Ö6 hariç diğer öğretmenler bu sorunun verilen cevabı için öğrencilerin tam sayılarda çıkarma işleminin eksilenin ters işaretlisi ile toplamak olduğunu unuttukları veya kavrayamamış oldukların ifade etmektedirler.

- ifadelerin önünde (sol taraf) bulunan işaretlerin ne anlama geldiğini kavramamış olabilirler. Iş̧aretlerin denklem çözümünde yer değiş̧irirken, işaret değiştirdiğini unutmuş olabilirler... (Ö4)

- Tam sayılarda çıkarma işlemi ile negatif sayıdaki işareti birbirinden farklı olarak anlamlandıramamıştır. (Ö8) 
Hülya SERT ÇELIK | Ercan MASAL

Ö3 ve Ö5 verilen cevap için dikkatsizlik sonucu oluşan bir hata olduğunu ifade etmektedirler.

- Burada öğrenci açısından -2 bulmasının iki farklı durumu olabilir. Birincisi, (-) işaretine dikkat etmemesi olabilir. Ikincisi, tamsayılarda toplama ve çıkarma işlemlerini bilmiyor olabilir.(Ö3)

- 43=45-? Ifadesinin yine 43,45 ve - 'yi görüp aceleci davranarak dikkatsizlik yaptıklarını düşünüyorum.(Ö5)

Ö6 nedenini çarpıcı şekilde tamsayılarda bölme işlemine bağlamaktadır.

- -?=-2 bulunmuş. Ve cevap -2 alınmıştır. Bu öğrencilerde çok karşılaştığım bir durum. Negatif sayıya dikkat edilmiyor. Tam sayılarla bölme işlemi eksik öğrenilmiş.

\subsection{2. Öğretmenlerin Öğrencilerin Kavram Yanılgıları Hakkındaki Tespitleri}

\subsubsection{PABA B2a öğretmen görüşleri ve bulgular}

$5(y+2)=30$ sorusunu öğrencilerin bir kısmının $5 y+10=30 \Rightarrow 15 y=30 \Rightarrow y=2$ işlemlerini yaparak cevapladıkları ve öğrencileri bu cevaba götüren kavram yanılgılarının ne olduğuna ilişkin görüşleri sorulduğunda, katılımcıların hepsinin cebirsel ifadelerde toplama işleminin öğrenciler tarafından anlaşılmadığına vurgu yaptıkları görülmektedir.

- Benzer terimlerin toplanacağı bilgisi eksik. Cebirsel ifadelerde toplama, çarpma (dört işlem) konuları kavratılmadan denklem çözme becerisini kazandırmak neredeyse mümkün değil. (Ö2)

- Bilinmeyen bir ifade ile sabit terimi ayırt edemiyor...(Ö5)

- Benzer terim tanımında kavram yanılgısına sahiptir. (Ö9)

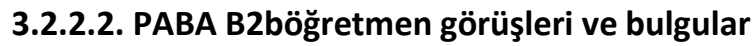

Hangi sayının 2 eksiğinin 3 katı 21'dir? sorusunu öğrencilerin bir kısmının x-2.3=21 şeklinde cevapladıkları ve öğrencileri bu cevaba götüren kavram yanılgılarının ne olduğuna ilişkin görüşleri sorulduğunda, katılımcıların öğrencilerin sözel olarak verilen bir duruma uygun cebirsel ifadeyi yazabilmelerine rağmen işlem önceliğini göz ardı ederek ve parantezi kullanmayarak ifadenin matematiksel olarak anlamını kaybetmesine neden olduğunu ve işlem önceliğine dikkat etmediklerini ifade ettikleri görülmüştür. Bu ise yanılgının tüm öğretmenler tarafından tanındığını göstermektedir.

Sözel olarak verilen cümleyi cebirsel ifade yardımıyla denkleme çevirirken öğrenci işlem önceliği kurallarını dikkate alması gerekirdi. x-2.3 yazdığında önce 2 ile 3 çarpıyor ama soruda ilk iki çıkarmayı yapması için $(x-2)$ şeklinde yazması gerektiğini atlamıştır.(Ö3) 
- Matematikte sözel ifadeleri matematiksel cümleye aktarırken zorluk yaşanmıştır. Işlem önceliği kavramı iyice oturtulmalı ve parantezin bir işlem sonucunu değiştirdiği vurgulanmalıdır. (Ö8)

Ö9 ise bunlara ilave olarak verilen sorunun öğrenciler tarafından tam olarak okuyup anlaşılmakta sıkıntı yaşandığını ifade etmektedir.

- Işlem önceliği ve okuduğunu anlama ile ilgili kavram yanılgısı vardır.(Ö9)

\subsubsection{3. $P A B A B 2 c$ öğretmen görüşleri ve bulgular}

Çözüm kümesi 4 olan bir denklem kurunuz? sorusunu öğrencilerin bir kısmının 8x4=4 gibi eşitliğin sağına 4 yazarak denklem kurarak cevapladıkları ve öğrencileri bu cevaba götüren kavram yanılgılarının ne olduğuna ilişkin katılımcılara görüşleri sorulduğunda, öğrencilerin = işaretini eşitlik bildiren bir sembol değil de cevabı işaret eden bir ifade olarak anladıkları, çözüm kümesini x'in alabileceği değerler olarak düşünmeyip ifadenin tümünün alacağı değer olarak düşündükleri öğretmenler tarafından ifade edilmiştir. Durumun katılımcılar tarafından tanındığını ve bu yanılgıyı fark ettiklerini söyleyebiliriz.

Çözüm kümesi ile eşitliğin 4'e eşit olmasını ayırt edememişler. Çözüm kümesinin, denklemde taraflardan birinin 4'e eşit olması gibi anlıyorlar. Soruda geçen değişkenin 4 olması değil de, eşitinin 4 olması olarak anlıyorlar.(Ö4)

- 8x-4 ile x'in sonucunun 4 olduğunu bir fark olmadığını düşünmüşlerdir. Yine bir kısım öğrenci çözüm kümesi kavramında çözüm sözcüğüne odaklanıp eşittir 4 sonucunu direk yazmışlardır.(Ö5)

- Çözüm kümesinin x'in değeri almak yerine eşitliğin sağ tarafı olduğuna dair yanılgıları vardır.(Ö10)

\subsection{3. Öğretmenlerin Öğrencilerin Anlama Güçlükleri Hakkındaki Tespitleri}

\subsubsection{PABA C2a öğretmen görüşleri ve bulgular}

Asya, 20 soruluk testteki tüm soruları yanıtlamıştır. Her doğru soru için 8 puan kazanmış, her yanlış cevapladığı soru için 3 puan kaybetmiştir. Asya, 20 sorudan $x$ tanesini yanlış yaptığında 61 puan aldığına göre, kaç soruyu doğru olarak yapmıştır? Problemin denklemini kurunuz ve çözünüz, sorusuna öğrencilerin bir kısmının 100-61=39 $\Rightarrow 3 K=39$ $\Rightarrow 13$ yanlış 7 doğru olarak cevapladıklarının görüldüğü ve öğrencilerin burada yaşadıkları anlama güçlüklerinin ne olduğuna ilişkin görüşleri sorulduğunda,

Ö8 ve Ö9; öğrencilerin sınav sonunda elde edilecek toplam puanın 100 olduğunu düşünerek, alışık oldukları sınav puanlamasına göre hareket ettiklerini ifade etmektedirler.

- Önceki öğrenmelerine göre sınavda alınan en yüksek notun 100 puan olarak bildiği için çözüm mantığı doğru olsa da çözümü yanlıştır. (Ö9) 
Hülya SERT ÇELIK | Ercan MASAL

Ö1 ve Ö10 soruda yaşanan anlama güçlüğünün çözümü için bu tip soruların iki bilinmeyen kullanarak denklemi çözmenin gerekliliğine vurgu yapmaktadırlar. Fakat 7.sınıf kazanımlarında bir bilinmeyenli denklemler anlatılmakta olup iki bilinmeyenli denklem kavramı 8.sınıfta verilmeye başlanmaktadır.

iki bilinmeyenli denklemleri kurma konusunda anlama güçlüğü çekmektedir. (Ö10)

Ö7 probleme uygun denklem yazabilme ve çözebilmenin matematik zekâsı yüksek öğrenciler tarafından yapılabildiğini dile getirmektedirler.

- Bu sorularda öğrenciler çok zorlanmakta, çok iyi matematik zekası olanlar anca çözebilmekte. Denklem kurmakta çok zorlanmaktalar. (Ö7)

Diğerleri ise probleme uygun yanlış denklem kurulduğunu ifade etmektedirler.

- 61 puan almayı pozitif artı bir durum olarak görüyor ve 39 puanı kaybettiğinden buna yanlışların sebep olduğunu düşünüyor. Yine problemin içinden her yanlıs soru 3 puan kaybettirir ifadesini görüp $3 k=39$ gibi denklem kuruyor. Yani problemi anlamıyor. (Ö5)

\subsubsection{PABA C2b öğretmen görüşleri ve bulgular}

$1 \mathrm{~kg}$ elma 5 lira ve $1 \mathrm{~kg}$ mandalina 6 liradır. Manavdan toplam $10 \mathrm{~kg}$ elma ve mandalina satın alınmış, karşılığında 55 lira ödenmiştir. Kaç kg mandalina satın alınmıştır? Problemin denklemini kurunuz ve çözünüz, sorusuna öğrencilerin bir kısmının, $10.5+6 x=55 \Rightarrow$ $6 x=5 \Rightarrow x=5 / 6$ olarak cevapladıklarının görüldüğü ve öğrencilerin burada yaşadıkları anlama güçlüklerinin ne olduğuna ilişkin görüşleri sorulduğunda,

Ö3 herhangi bir görüş bildirmemekte, Ö2, Ö4, Ö5, Ö6, Ö8 ve Ö9 öğrencilerin problemi yanlış anlayıp, yanlış denklem kurduklarını söylemektedirler. Öğrenciler, yalnızca elmanın 10 kg olduğunu düşünüp elma ve mandalinanın kilolarını tek değişkene bağlı x ve 10-x şeklinde yazamayarak anlamsal olarak problemi kavrayamamışlardır.

- $10 \mathrm{~kg}$ elma ve mandalina ifadesindeki, $10 \mathrm{~kg}$ değerinin hem elma hem de mandalinaya ait olduğunu düşünmüşler ancak çözümü, her iki değeri de bilmelerine rağmen sanki birini bilmiyormuş gibi yapmışlar. Verilen ile isteneni anlamamışlar. Hem $10 \mathrm{~kg}$ mandalina, $10 \mathrm{~kg}$ elma mandalina varmış gibi başlamış, bilmelerine rağmen mandalina bulmuşlar. (Ö4)

Ö1 ve Ö10 iki bilinmeyenle denklem çözme mantığında anlama güçlüğüne vurgu yapmaktadırlar. olur. (Ö1)

Bu tip soruları genelde iki bilinmeyenli denklemle çözdürmek daha doğru 
Ö7 ise iki bilinmeyen olarak düşündükleri için denklem kuramadıklarını ifade etmektedir.

- Yukarıdaki örnekle aynı sorunlarla karşılaşmışlar, iki bilinmeyen olarak düşündükleri için denklem kuramamışlar. (Ö7)

\subsubsection{3. $P A B A C 2 c$ öğretmen görüşleri ve bulgular}

$6 \square+17=35,6 \square+17-8=35-8$ Verilen iki denklemde de kutuların yerlerine yazılması gereken sayılar aynı mıdır? Sorusunun cevabına öğrencilerin yarısına yakını kutuların içine gelecek sayıları denklemi çözerek bulmuşlardır. Öğrencilerin burada yaşadıkları anlama güçlüklerinin ne olduğuna ilişkin görüşleri sorulduğunda,

Ö5 ve Ö6 bu durumu denklemi çözmenin ifadelerin aynı olduğuna emin olabilmekle eş değer gördüğünü ve bunda sakınca olmadığını ifade etmektedirler.

- Aynı olup olmadığını ikisinin de sonucunu bularak (sayısal değer) çözmek istemişlerdir. Bu şekilde aynılığından emin olunabilir düşüncesi hâkimdir. Soruyu inceleyerek cevap verebilecek yeterliliğe sahip olan öğrenciler bile sonuç (sayısal değer) odaklı düşünmüşlerdir. (Ö5)

Ö7 ise farklı bir bakış açısıyla ilkokulda bilinmeyen yerine bu şekiller kullanıldığı için şekilleri bilinmeyen olarak kabul edip denklem çözümü yapmışlardır yargısını ifade etmektedir.

- Ilkokulda bilinmeyen yerine bu şekiller kullanıldığı için şekilleri bilinmeyen olarak kabul edip denklem çözümü yapmışlardır.(Ö7)

Ö2 herhangi bir görüş dile getirmemiş olup Ö1, Ö3, Ö4, Ö8, Ö9 ve Ö10 eşitliğin korunumu ilkesi hakkında sıkıntı yaşadıklarını dile getirmektedirler.

- Eşitliğin korunumunu hatırlayamamışlar. Eşitliği, bir terazi gibi düşünmeleri sağlanıp, bir tarafa herhangi bir müdahale yapıldığında diğer tarafa da aynı müdahalenin yapılması gerektiğini bilmeleri gerekmektedir. (Ö4)

- Denge kavramını anlayamamışlardır. Eşitlikte her iki tarafa aynı işlemler uygulandığında eşitlik bozulmaz kazanımını öğrenci kavrayamamıştır ve denklem çözme yolunu tercih etmiştir.(Ö8)

Bunun gibi basit eşitliklerin çözümü öğrencilerin eşitliğin her iki tarafını eş değer ifadeler olarak görmelerini gerektirir. Öğrencilere matematiksel düşünme becerisi kazandırmak yerine matematiksel işlem yapmakla öğrencilerde de matematiğin sadece işlem yapmaktan ibaret olduğu algısını oluşturmakta ve eşitliğin "her iki tarafın aynı olması/denge" anlamından öte bir şeyin sonucuna ulaştırması, eşitliğin karşısının cevap olması gerektiği düşüncesi burada olduğu gibi öğrencileri işlem yüküne maruz bırakmaktadır. 
Hülya SERT ÇELIK | Ercan MASAL

\section{3. Öğretmenlerin Öğrenci Bilgisi Bileşeni Hakkındaki Çözüm Önerileri}

\subsubsection{PABA A3 öğretmen görüşleri ve bulgular}

Öğretmenlere öğrencilerin bu hataları yapmamaları için derslerinde ön bilgi-yeni bilgi arasında nasıl bağlantı kurdukları sorulduğunda,

Ö8, 6.sınıf kazanımlarından tamsayılar ve işlemler konusunu, Ö9 ise 6.sınıf kazanımlarından cebirsel ifadeler konusunun tekrar ettikten ve yeterince soru çözdükten sonra yeni konu olan eşitlik ve denklem konusuna geçilmesi gerektiğini ifade etmektedirler.

- Öğrencilerin ön bilgilerinin yeterli olması durumunda eşitlik ve denklem konusuna geçilmelidir.6.sınıf tamsayılar ve tamsayılarda işlemler konuları iyice pekiştirildikten sonra denklemlere yer verilmelidir.(Ö8)

- Önce cebirsel ifade yazma çalışmaları yapıp 6.sınıf kazanımlarını tekrar ederim. Daha sonra denklem çözme adımlarını anlatıp akıllı tahtada öğrencilere alıştırmalar yaptırırım. Ayrıca tamsayılarda dört işlemi kısaca gösterip örnek çözdügüümüz zaman denklem çözme konusu daha rahat işleniyor. (Ö9)

Ö1 ve Ö6 konu tekrarlarından ve bol soru çözmekten, Ö2, Ö3, Ö7 ve Ö10 ise genelleme yaparak matematik dersi adına konuların birbirine bağlantılı olduğunu, yeni bilgi öğrenilmesi için ön bilgilere ihtiyaç olduğundan bahsetmektedirler.

- Çok fazla örnek çözerim. Tamsayılar konusuna yeniden dönüş yapıp hatırIatma yaparım.(Ö1)

- Öğrencilerin yeni bir bilgiyi öğrenebilmeleri için (o bilginin öğrenilebilmesi için) gerekli ön bilgilerin mutlaka verilmesi gerekir. Yani hazırbulunuşlukları çok önemli. Matematikte konular zincirin halkaları gibi birbiriyle bağlantılı. (Ö2)

- Konuya başlamadan önce ön kazanımları mümkün olduğunca baştan alıp, en alt seviyede anlatmaya çalışıyorum. Hata yapma olasılıkları en yüksek örnekleri sınıfta çözmeye çalışıyorum. (Ö7)

Ö4 ve Ö5 ise denklem çözmeyi çocuklara anlatırken kullandıkları öğretim stratejisinden bahsetmektedirler.

Bilinmeyenler bir tarafa, sayılar bir tarafa diyorum. Ardından eksiler çocukları yanılttıkları için; büyük olan x yerinde kalsın küçükler bayram ziyaretine gider diyorum ve küçük katsayılı $x$, işaret değiştirerek büyügü̈n yanına geliyor. Böylelikle eşitliğin bir tarafı tamamlanıyor. x'ler yerini seçti, kalan bölge sayıların deyip sayıları diğer tarafa topluyorum. (Ö5) 


\subsubsection{PABA $B 3$ öğretmen görüşleri ve bulgular}

Öğretmenlere öğrencilerin sahip oldukları bu kavram yanılgıların giderilmesi için derslerinde neler yaptıkları sorulduğunda,

Ö1, Ö2 öğrencilere kavramların iyi kavratılması gerektiğini söylemektedir fakat bunların nasıl yapılacağına dair açıklayıcı bir ifadeye yer vermemektedirler.

- Çözüm kümesi kavramı, işlem önceliği, bilinmeyen, değişken, benzer terim ifadeleri kavratılmalı. (Ö2)

Ö9 ve Ö10 eğitim kuramına ve konuların müfredattaki yapılanmasına dikkat çeken genel bir açıklama yapmışlardır.

- Öğretmen merkezli eğitim-öğretimden vazgeçip öğrenci merkezli eğitim öğretime geçilmelidir. Sorgulayan, araştıran öğrenci yetiştirmeliyiz. (Ö9)

- Konuların daha iç içe olması gerekmektedir. (Ö10)

Ö3, Ö4, Ö6, Ö7 ve Ö8 cebirsel ifadelerin ve denklem konusunun içinde yer alan temel kavramların daha iyi öğretilmesini ifade etmekte fakat bunların nasıl yapılacağına dair fikir sunmamaktadırlar.

- Öğrencilere öncelikle hazır denklem yerine, denklem kurduracak sözel ifadelerden faydalanılmalı. Soruyu verip cevabı istemektense, cevabı verip soruyu kendi yazmalarını istemek onların bu konu hakkında ki eksiklerini görmede öğretmene bilgi verecektir. Öğrenciye hangi işlemi hangi bilgiye dayanarak yaptığını işlemin yanına yazdırarak kalıcı öğrenme sağlanmalı. (Ö3)

- Cebirsel ifadeler üzerinde çok durulmalı, eşitliğin korunumu iyi kavratılmalı, denklem konusu ilk basit olarak 6. sınıfta verilmeli. İşlem önceliği çok iyi kavratılmalı. Kesirlerde işlemler tam olarak öğretilmeli. (Ö7)

Ö5 ve Ö6 bol soru çözmekle bu yanılgıların aşılabileceğini ifade etmektedirler.

- Konuya girişte bu kavramlar tek tek tanıtılıp bol örnekle pekiştirilebilir. Benzer fakat yanılgı yaratabilecek örnekler ardı ardına çözülüp farkına dikkat çekilebilir. (Ö5)

\subsection{3. $P A B A C 3$ öğretmen görüşleri ve bulgular}

Öğretmenlere öğrencilerinin yaşadıkları anlama güçlüklerini gidermek için derslerinde neler yaptıkları sorulduğunda,

Ö1, Ö6 ve Ö10 bol soru çözümüyle konudaki anlama güçlüklerinin giderilebileceğine vurgu yapmaktadırlar.

- Bol örnek çözüyorum. Bilinmeyenler yerine elma, armut gibi kavramlar koyuyorum. (Ö1)

- Onlara sık sık tahtaya kalkma ve çok örnek çözme şansı veriyorum. (Ö6) 
Ö2 ve Ö7 konu için gerekli ön bilgilerin hatırlatılmasının gerekli olduğunu ifade etmektedirler.

- Mümkün olduğunca ön bilgilerin eksikliğini tamamlamaya çalışıyorum. Konuyu en basit şekilde ve somutlaştırarak anlamaya çalışıyorum. (Ö7)

Ö3 soru çözümünde farklı yollar deneme ile güçlüklerin aşılacağını dile getirmektedirler.

- Verilen bir sorunun farklı çözüm yollarını, konu içerisindeki bilgiler ışığında çözüyoruz. (Ö3)

Ö4 konu anlatımında soyut olan kavramları somutlaştırarak anlattığına vurgu yapmaktadır.

- Konuyu önce hangi sınıf seviyelerinde ve ne kadar derin göreceklerini anlatıyorum. Konuda yapılacak bazı can alıcı noktaları kolay kavramaları için hikâyeleştirme yada gerçek hayattan örnekleyerek zihinlerinde tutmaya çalışıyorum. İsaretlerin (+ ve -) ne ifade ettiğini anlatıyorum. Cinsiyet kavramından örnek veriyorum. Kedi-köpek sayılarını farklı ifadeler oldukları için ayrı ayrı söylemek gerektiğini tek seferde toplamalarını söyleyemeyeceğimizi hatırlatıyorum. Terazi örneğini anlatıyorum. Pazarlarda eşit kollu terazide ağırlık ve alınan ürünü dengelemek için yapılan müdahale gibi. Değişken ve sabit ifadelerin neyi anlattığını hatırlatıyorum. İşlem öncelik sırasını, trafikteki araçlardan örnek vererek (ambulans, itfaiye $v b$ ) anlatıyorum. (Ö4)

Ö5 planda ayrılan zamanın yeterli olmadığını ve konunun iyice yerleşmesi için aynı tip soru kalıplarının farklı rakamlar kullanarak çözmenin faydalı olduğu kanısındadır.

- 7. Sınıfın en temel ve en önemli konularının başında gelen denklemler konusu için, planda ayırdığım zamanı aşabiliyorum. Soru kalıbını yerleştirmek için her soru tipinden sadece rakamları değiştirip bolca soru çözüyorum. Bunu yaparken de öğrencileri öğrenme ortamına aktif katıyorum. Benzer fakat ince farklııklar olan soruları art arda çözüyorum. (Ö5)

Ö8 ise konunun güzelce anlatılıp videolarla desteklenirse öğrenmenin kalıcı olacağını ifade etmektedir.

Öğrenciye eşitlik kavramını güzelce anlatıp, günlük hayattan örnekler vermek gerekir. En basiti bir terazi sınıfa getirilebilir. Okulumuzda akılı tahta olmadığı için görsel anlamda hitap edemiyorum. Ama daha teknolojik okullarda videolar izletilerek öğrenme daha kalıcı hale getirilebilir. (Ö8)

Ö9 ise akıllı tahtalar sayesinde bol soru çözmekle kavram yanılgılarının üstesinden gelineceğini dile getirmektedir. 
- Ders esnasında öğrencilerle beraber tanımı buluyoruz. Küçük ipuçları ve sorularla yönlendirme yapıyoruz. Dersin amacını(kazanım olarak) en başta belirtiyorum. Etkileşimli tahta sayesinde bol soru çözerek kavram yanılgılarına engel olmaya çalışıyoruz. Ev için verilen çalışma kâğıtlarının kontrolünü sınıfta mutlaka yapıyoruz. Her soru tipiyle ilgili örnekleri sınıfta öğrenciler çözüyor. Ayrıca konu bitiminde tekrar testi veya quizlerle son dönütü alıyorum. (Ög)

\section{Tartışma ve Sonuç}

Ilköğretim matematik öğretmenlerinin eşitlik ve denklem konusuna yönelik pedagojik alan bilgilerini öğrenci bileşenini oluşturan, öğrencilerinin sahip olmasını bekledikleri ön bilgileri, öğrencilerinin sahip oldukları kavram yanılgıları ve öğrencilerinin yaşadıkları öğrenme güçlükleri açısından inceleyen bu araştırma ile:

Eşitlik ve denklem konusunda öğrencilerin sahip olması beklenilen ön bilgi-yeni bilgi bileşenine yönelik olarak öğretmenlerin verdiği cevaplardan elde edilen bulgulara göre, öğretmenlerin konu öğretimi için öğrencilerinin sahip olması gereken ön bilgileri hakkında istenilen düzeyde bilgiye sahip olmadıkları ve öğretim programı bilgilerinde de eksiklikler olduğu görülmektedir. Bu durum matematik öğretmenleri ve aday öğretmenlerle yapılan bazı araştırma sonuçlarıyla da örtüşmektedir (Baki, 2012; Baştürk ve Dönmez, 2011; Bingölbali, 2010; Black, 2007; Bütün, 2012; Eroğlu, 2012; Gökbulut, 2010; Karahasan, 2010; Kutluk, 2011; Gökkurt ve Soylu, 2016; Gökkurt vd., 2015; Tanışlı ve Köse, 2013).

Öğretmenlerin konu için gerekli ön bilgilerin farkında olarak öğretimi planlaması, öğrencilerin konunun öğreniminde yaşayabilecekleri olumsuzlukların önüne geçebilmesi açısından önemlidir. Ön bilgiler kendilerini izlemekte olan yeni bilgilerin öğrenilmesi için gerekli bilgileri sunmaktadır ve iyi yapılandırılmış ön bilgiler, öğrencinin dikkatini yeni öğrenilecek bilginin önemli noktalarına vermesine, eski ve yeni kavramlar arasındaki ilişkileri, benzerlik ve farklııkları fark edebilmesine olanak sağlamaktadır. Katıımcılar genelde ön bilgi eksikliğini konu ile ilgili daha fazla soru çözerek gidermeye çalışmakta, ön bilgi eksikliğinden kaynaklı öğrenci hatalarını ise öğrenciye bağlayarak dikkatsizlik ve unutma olarak açıklamaktadırlar. Gökkurt vd. (2015) öğrenci hatalarının tespit edilebilmesi için öğretmenlerin konu alan bilgilerinin ve öğrencileri anlama bilgilerinin yeterli seviyede olması gerektiğini ifade etmektedirler. Boz (2004) öğrenci hatalarını belirlemek ve bunları detaylı irdelemede öğretmenlerin alan bilgilerinin çok önemli olduğunu vurgulamakta, Reynolds (1992) ise öğretmenlerin, öğrencilerini anlamalarının etkili ve sağlıklı bir öğretim için çok önemli olduğunu ifade etmektedir.

Eşitlik ve denklem konusunda öğrencilerinin sahip oldukları kavram yanılgıları bileşenine yönelik olarak öğretmenlerin verdiği cevaplardan elde edilen bulgulara göre, öğretmenlerin öğrencilerin sahip oldukları kavram yanılgıları hakkında net görüş bildiremedikleri, matematiğin genel özellikleri ve sağlam temellendirme gibi içini dolduramadıkları yüzeysel açıklamalarda bulundukları görülmektedir. Öğretmenlerin çoğu öğrencilerin 
Hülya SERT ÇELIK | Ercan MASAL

sahip oldukları kavram yanılgılarını "hata" olarak tanımlamakta ve konuya yönelik var olan kavram yanılgılarını öğrenci hataları şeklinde ifade etmektedirler. Ayrıca konu öğrenimi için gerekli olan kazanımlara sahip olunamayışını da kavram yanılgısı olarak nitelendiren öğretmenlerin de var olduğu görülmektedir ve bu durum Akkaş (2014)'ün yaptığı çalışmayla paralellik göstermektedir.

Katılımcıların öğrencilerin sahip oldukları kavram yanılgılarının önüne geçebilmek için herhangi bir çalışma yapmadıkları, bir kısmının konuya özgü kavram yanılgılarını bilmedikleri için görmezden geldikleri, bir kısmının da kavram yanılgılarına hata olarak yaklaştıkları görülmektedir. Hacıömeroğlu (2005) matematik öğretmeni adaylarının alan ve pedagojik alan bilgilerinin istenilen düzeyde olmadığını vurgulamakta ve öğretmen adaylarının öğrencilerinin sahip olduğu kavram yanılgılarını tespitte ve kaynağını belirleme konusunda zorlandıklarını açıklamaktadır ki bu sonuçlar çalışmadan elde edilen verilerle de tutarlılık göstermektedir.

Eşitlik ve denklem konusunda öğrencilerinin yaşadıkları anlama güçlükleri bileşenine yönelik olarak öğretmenlerin verdiği cevaplardan elde edilen bulgulara göre, öğretmenlerin en çok öğrencilerin verilen probleme uygun denklem yazarak çözebilme konusunda güçlük yaşadıklarını tespit ettikleri görülmektedir. Bu sonuç bazı araştırma sonuçlarıyla da tutarlılık göstermektedir (Akgün, 2007; Baysal, 2010; Çavuş Erdem, 2013; Stacey ve McGregor, 1997). Öğrencilerin cebirsel ifade yazma ile ilgili olarak karşılaştıkları ve yaşadıkları güçlüğü katılımcıların hepsinin doğru olarak tespit edebildikleri görülmektedir ve bu durum Gökkurt, Şahin ve Soylu (2016) çalışmasıyla paralellik göstermektedir. Öğrencilerin problem çözümlerinde en çok mantık hatasına düştükleri, soru kökünün yeterince iyi okunmadığı araştırmadan elde edilen diğer sonuçlardandır.

Ball (1991) öğretmenin alan bilgisinin, öğrencilerin öğretilen konular hakkındaki öğrenme zorluklarının belirlenmesinde ve anlaşılmasında büyük bir paya sahip olduğunu dile getirmektedir. Katılımcıların büyük bir kısmı denklemlerin çözümü sırasında toplama veya çıkarma durumundaki bir ifadenin eşitliğin karşı tarafına geçtiğinde işaret değiştirmesine sebep olan matematiksel gerekçeyi açıklarken bunun bir kural ve/ veya dikkatsizlik kaynaklı oluşabileceğini ifade etmektedirler. Bütün (2012) öğretmen adaylarının denklem çözme konusunda sonuca doğrudan ulaşmayı sağlayan kurallar verdiklerini ve öğretimsel süreçlerini sonuç odaklı yapılandırdıklarını belirtmişlerdir. Bu durum birçok çalışmanın sonuçlarında yer alan öğretmenlerin matematiği bir kurallar bütünü olarak düşünüp öğrencilere matematik öğretiminde kurala bağlı öğretim yaptıkları ile paralellik göstermektedir (Akgün, 2007; Baştürk, 2009; Bütün, 2012). Diğer taraftan öğretmenlerin, öğrencilerin sahip oldukları kavram yanılgılarını, ön bilgi eksikliklerini ve yaşadıkları anlama güçlüklerini açıklarken matematik dilini etkin bir şekilde kullanamadıkları da görülmektedir ve yine bu durum Gökkurt, Şahin ve Soylu (2016) yaptığı çalışmayla örtüşmektedir. 
Bu çalışma sonucunda elde edilen verilerden öğretmenlerin pedagojik alan bilgisinin alt bileşenlerinden olan öğrenci bilgisi bileşeni hakkında eşitlik ve denklem konusuna yönelik bilgi düzeylerinin yeterli olmadığını söylenebilir. Bu durum literatürde yer alan birçok çalışma sonucuyla paralellik göstermektedir (Ball, 1990a, 1990b; Black, 2007; Borko vd., 1992; Erskine, 2010; Gökkurt vd., 2015; Hacıömeroğlu, 2005; Işıksal, 2006; Lubinski, Fox, ve Thomason, 1998; Ma, 1999; Nagle ve McCoy, 1999; O'Hanlon, 2010; Tanışlı ve Köse, 2013; Tirosh, 2000; Toluk-Uçar, 2011; Şahin vd.,2013; Şahin vd.,2014).

Bu çalışmaya benzer çalışmaların diğer matematik konularında da yapılması ve pedagojik temellerinin ortaya konulması, ortaokul matematik öğretmenlerinin denklem ve eşitlik konusuna ait pedagojik alan bilgilerinin istenilen düzeyde olmadığından hareketle eksiklerin giderilmesi için hizmet içi eğitim seminerleri-çalıştaylar düzenlenmesi, anlama güçlüklerinin, sık rastlanan kavram yanılgılarının ve konu için gerekli ön bilgilerinin yer alacağı öğretmenleri bilgilendirici kılavuz kitaplarının hazırlanması matematik öğretiminin kalitesini arttıracağı düşünülmekte ve bu çalışmanın önerileri olarak ifade edilebilir.

\section{Kaynaklar}

Akgün, L. (2007). Değişken Kavramına İlişkin Yeterlilikler ve Değişken Kavramının Öğretimi. Yayımlanmamış doktora tezi, Atatürk Üniversitesi, Fen Bilimleri Enstitüsü.

Akkaş, E. N. (2014). Ortaokul 5. ve 7. Sınıf Matematik Öğretmenlerinin Geometri Öğretim Süreçlerinin ve Geometrik- Pedagojik Alan Bilgilerinin İncelenmesi. Doktora Tezi, Dokuz Eylül Üniversitesi, Eğitim Bilimleri Enstitüsü.

Akkaya, R. ve Durmuş, S. (2006). İlköğretim 6-8. Sınıf Öğrencilerinin Cebir Öğrenme Alanındaki Kavram Yanılgıları. Hacettepe Üniversitesi Eğitim Fakültesi Dergisi, 31,112.

An, S., Kulm, G. and Wu, Z. (2004). The Pedagogical Content Knowledge of Middle School, Mathematics Teachers in China and The U.S. Journal of Mathematics Teacher Education, 7, 145-172.

Asquith, P., Stephens, A. C., Knuth, E. J. and Alibali, M. W. (2007). Middle School Mathematics Teachers' Knowledge Of Students' Understanding Of Core Algebraic Concepts: Equal Sign And Variable. Mathematical Thinking and Learning, 9(3), 249-272.

Baki, M. (2012). Sınıf Öğretmeni Adaylarının Matematiği Öğretme Bilgilerinin Gelişiminin İncelenmesi: Bir Ders İmecesi (Lesson Study) Çalışması. Yayımlamamış doktora tezi, Karadeniz Teknik Üniversitesi Eğitim Bilimleri Enstitüsü.

Ball, D. L. (1990a). The Mathematical Understandings That Prospective Teachers Bring to Teacher Education. The Elementary School Journal, 90(4), 449466.

Ball, D. L. (1990b). Prospective Elementary and Secondary Teachers Understanding of Division. Journal for Research in Mathematics Education, 21(2), 132144. 
Hülya SERT ÇELIK | Ercan MASAL

Ball, D. L. (1991). Research on Teaching Mathematics: Making Content Knowledge Part of The Equation. In J. Brophy (Ed.), Advances in Research on Teaching (Vol. 2, pp. 148). Greenwich, CT: JAI Press.

Ball, D.L. and Bass, H. (2000). Interweaving content and pedagogy in teaching and learning to teach: Knowing and using mathematics. In J. Boaler (Ed.), Multiple Perspectives on Mathematics of Teaching and Learning. (pp. 83104). Westport, Conn.: Ablex Publishing.

Ball, D. L., Thames, M. H. and Phelps, G. (2008). Content Knowledge for Teaching: What Makes It Special? Journal of Teacher Education. 59(5), 389- 407.

Baştürk, S. (2009). Ortaöğretim Matematik Öğretmen Adaylarına Göre Fen Edebiyat Fakültelerindeki Alan Eğitimi. Inönü Üniversitesi Eğitim Fakültesi Dergisi, 10(3), $137-$ 160.

Baştürk, S. and Dönmez, G. (2011). Examining Pre-Service Teachers' Pedagogical Content Knowledge with Regard to Curriculum Knowledge. International Online Journal of Educational Sciences, 3(2), 743-775.

Baumert, J., Kunter, M., Blum, W., Brunner, M., Voss, T., Jordan, A., and . . .Tsai, Y.-M. (2010). Teachers' mathematical knowledge, cognitive activation in the classroom, and student progress. American Educational Research Journal, 47, 133-180. doi:10.3102/0002831209345157

Baysal, F. K. (2010). İlköğretim Öğrencilerinin (4-8. Sınıf) Cebir Öğrenme Alanında Oluşturdukları Kavram Yanılgıları. Yayınlanmamış yüksek lisans tezi, Abant İzzet Baysal Üniversitesi, Sosyal Bilimler Enstitüsü.

Behr, M., Erlwanger, S. and Nichols, E. (1980). How Children View The Equal Sign. Mathematics Teaching, 92, 13-15.

Bingölbali, F. (2010). Matematik Öğretimi Etkinlik Uygulamalarında Karşılaşılan Öğrenci Zorluklarının Nedenleri ve Öğretmen Müdahale Türleri. Yayımlanmamış yüksek lisans tezi, Gaziantep Üniversitesi, Sosyal Bilimler Enstitüsü.

Black, D. J. W. (2007). The Relationshıp of Teachers' Content Knowledge and Pedagogical Content Knowledge in Algebra, and Changes in Both Types of Knowledge As a Result of Professional Development. Doctoral Disertation, Auburn University, USA.

Borko, H. and Putnam, R. T. (1996). Learning to teach. In D. C. Berliner \& R. C. Calfee (Eds.), Handbook of educational psychology (pp. 673-708). Washington, DC: Macmillan. 
Borko, H., Eisenhart, M., Brown, C. A., Underhill, R. G., Jones, D. and Agard, P. C. (1992). Learning to Teach Hard Mathematics: Do Novice Teachers and Their Instructors Give Up Too Easily? Journal for Research in Mathematics Education, 23, 194-222.

Boz, N. (2004). Öğrencilerin Hatasını Tespit Etme ve Nedenlerini İrdeleme. XIII. Ulusal Eğitim Bilimleri Kurultayı, 6-9, İnönü Üniversitesi Eğitim Fakültesi, Malatya.

Bransford, J., Darling-Hammond, L. and LePage, P. (2005). Introduction. In L. DarlingHammond and J. Bransford (Eds.), Preparing teachers for a changing world (pp. 139). San Francisco: Jossey-Bass.

Bransford, J. D., Derry, S. J., Berliner, C. D. and Hammerness, K. (2005). Theories of learning and their roles in teaching. In L. Darling-Hammond and J. Bransford (Eds.), Preparing teachers for a changing world (pp. 40-87). San Francisco: Jossey-Bass.

Bütün, M. (2012). İlköğretim Matematik Öğretmeni Adaylarının Uygulanan Zenginleştirilmiş Program Sürecinde Matematiği Öğretme Bilgilerinin Gelişimi. Yayımlanmamış doktora tezi. Karadeniz Teknik Üniversitesi, Eğitim Bilimleri Enstitüsü.

Büyüköztürk, S., Kılıç-Çakmak, E., Akgün, Ö.E., Karadeniz, S. ve Demirel, F. (2008). Bilimsel Araştırma Yöntemleri. Ankara: Pegem Akademi Yayıncılık.

Carpenter, T. P. and Levi, L. (2000). Developing Conceptions of Algebraic Reasoning in the Primary Grades. Research Report Madison, WI: National Center.

Çakmak Gürel, Z. ve Okur, M. (2017). 7. ve 8. sınıf öğrencilerinin eşitlik ve denklem konusundaki kavram yanılgıları. Cumhuriyet International Journal of Education, 6(4), 479-507.

Çavuş Erdem, Z. (2013). Öğrencilerin Denklem Konusundaki Hata ve Kavram Yanılgılarının Belirlenmesi ve Bu Hata ve Yanılgıların Nedenleri ve Giderilmesine Ilişkin Öğretmen Görüşleri. Yayımlanmamış yüksek lisans tezi, Adıyaman Üniversitesi, Fen Bilimleri Enstitüsü.

Dede, Y. ve Argün, Z. (2003). Cebir Öğrencilere Niçin Zor Gelmektedir? Hacettepe Üniversitesi Eğitim Fakültesi Dergisi, 24, 180-185.

Dede, Y., Yalın, H. ve Argün, Z. (2002). İlköğretim 8. Sınıf Öğrencilerinin Değişken Kavramının Öğrenimindeki Hataları ve Kavram Yanılgıları. V. Ulusal Fen Bilimleri ve Matematik Eğitimi Kongresinde Sunulan Bildiri, Orta Doğu Teknik Üniversitesi, Ankara.

Erbaş, A.K., Çetinkaya, B. ve Ersoy, Y. (2009). Öğrencilerin Basit Doğrusal Denklemlerin Çözümünde Karşılaştıkları Güçlükler ve Kavram Yanılgıları, Eğitim ve Bilim, 34(152), p.44-59. 
Hülya SERT ÇELIK | Ercan MASAL

Eroğlu, D. (2012). Examining Prospective Elementary Mathematics Teachers Knowledge About Students Mistakes Related to Fractions. Master degree, Middle East Technical University: Ankara.

Ertekin, E. (2002). Denklemlerin Öğretimindeki Yanılgıların Teşhisi ve Sebeplerinin Belirlenmesi. Yayınlanmamış yüksek lisans tezi. Selçuk Üniversitesi, Fen Bilimleri Enstitüsü.

Erskine, B. M. (2010). Raising Mathematical Achievement Starts with The Elementary Teacher: Recommendatıons to Improve Content and Pedagogıcal Knowledge of Elementary Math Teachers. Doctoral Dissertation, University of Delaware, USA.

Falkner, K., Levi, L. and Carpenter, T. (1999). Children's Understanding of Equality: A Foundation for Algebra. Teaching Children Mathematics, December, 232-236.

Grossman, P. L. (1990). The Making of a Teacher. Teacher Knowledge and Teacher Education. New York: Teachers College Press.

Grossman, P. L. (1995). Teachers' knowledge. In L. W. Anderson (Ed.), International encyclopedia of teaching and teacher education (Vol. 2, pp. 20-24). Oxford, UK: Pergamon Press.

Grossman, P. L. and Schoenfeld, A. (2005). Teaching subject matter. In L. Darling Hammond, J. Bransford, P. LePage, K. Hammerness \& H. Duffy (Eds.), Preparing teachers for a changing world: What teachers should learn and be able to do (pp. 201-231). San Francisco: Jossey-Bass.

Grossman, P. L. and McDonald, M. (2008). Back to the future: Directions for research in teaching and teacher education. American Educational Research Journal, 45(1), 184205.

Gökbulut, Y. (2010). Sınıf Öğretmeni Adaylarının Geometrik Cisimler Konusundaki Pedagojik Alan Bilgileri. Yayınlanmamış doktora tezi, Gazi Üniversitesi, Eğitim Bilimleri Enstitüsü.

Gökkurt, B., Şahin, Ö., Soylu, Y. ve Doğan, Y. (2015). Öğretmen Adaylarının Geometrik Cisimler Konusuna İlişkin Öğrenci Hatalarına Yönelik Pedagojik Alan Bilgileri. ilköğretim Online, 14(1), 55-71.

Gökkurt, B. ve Soylu, Y. (2016). Ortaokul Matematik Öğretmenlerinin Pedagojik Alan Bilgilerinin Bazı Bileşenler Açısından İncelenmesi: Koni Örneği. Ilköğretim Online, 15(3), 946-973. DOI:10.17051/io.2016.14548. 
Gökkurt, B. Şahin, Ö. ve Soylu, Y. (2016). Öğretmen Adaylarının Değişken Kavramına Yönelik Pedagojik Alan Bilgilerinin Öğrenci Hataları Bağlamında İncelenmesi. Pamukkale Üniversitesi Eğitim Fakültesi Dergisi, 39 (39), 17-31. Retrieved from http://dergipark.gov.tr/pauefd/issue/33882/375163.

Gürbüz, R. ve Akkan, Y., (2008). Farklı Öğrenim Seviyesindeki Öğrencilerin Aritmetikten Cebire Geçiş Düzeylerinin Karşılaştırılması: Denklem Örneği. Eğitim ve Bilim, 33(148), 64-76.

Haciömeroğlu, G. (2005). Prospective Secondary Teachers' Subject Matter Knowledge and Pedagogical Content Knowledge of the Concept of Function. Doctoral dissertation, The Florida State University, USA.

Hiebert, J., Morris, A. K., Berk, D. and Jansen, A. (2007). Preparing teachers to learn from teaching. Journal of Teacher Education, 58(1), 47-61.

Hill, H. C., Rowan, B. and Ball, D. (2005). Effects of teachers' mathematical knowledge for teaching on student achievement. American Educational Research Journal, 42(2), 371-406.

Hoch, M. and Dreyfus, T. (2004). Structure Sense in High School Algebra: The Effect of Brackets. Proceedings of the 28th Conference of the International Group for the Psychology of Mathematics Education, 3, 49-56.

Işıksal, M. (2006). A Study on Pre-service Elementary Mathematics' Subject Matter Knowledge and Pedagogical Content Knowledge Regarding the Multiplication and Division of Fractions. Unpublished doctoral dissertation, Middle East Technical University, Department of Secondary Science and Mathematics Education.

Jacobs, V. R., Franke, M. L., Carpenter, T. P., Levi, L. and Battey, D. (2007). Professional Development Focused on Children's Algebraic Reasoning in Elementary School. Journal for Research in Mathematics Education, 38(3), 258-288.

Karahasan, B. (2010). Preservice Secondary Mathematics Teachers' Pedagogical Content Knowledge of Composite and Inverse Functions. Unpublished doctoral dissertation, Middle East Technical University, Department of Secondary Science and Mathematics Education.

Kieran, C. (1992). The Learning and Teaching of School Algebra. In D. A. Grouws (Ed.), Handbook of Research on Mathematics Teaching and Learning. Reston, VA: National Council of Teachers of Mathematics, 706-762.

Kutluk, B. (2011). İlköğretim Matematik Öğretmenlerinin Örüntü Kavramına İlişkin Öğrenci Güçlükleri Bilgilerinin İncelenmesi. Yayımlanmamış yüksek lisans tezi, Dokuz Eylül Üniversitesi, Eğitim Bilimleri Enstitüsü. 
Hülya SERT ÇELIK | Ercan MASAL

Lubinski, C. A., Fox, T. and Thomason, R. (1998). Learning to Make Sense of Division of Fractions: One K-8 Pre-service Teacher's Perspective. School Science and Mathematics, 98(5),247-253.

Ma, L. (1999). Knowing and Teaching Elementary Mathematics: Teachers' Understanding of Fundamental Mathematics in China and the United States. Mahwah, NJ: Erlbaum.

Magnusson, S., Krajcik, J. and Borko, H. (1999). Nature, Sources and Development of Pedagogical Content Knowledge for Science Teaching. In J. Gess Newsome and N.G. Lederman (Eds.), Examining Pedagogical Content Knowledge. (95-132). Dordrecht, The Netherlands: Kluwer Academic Publishers.

MEB (2013). Matematik Dersi Öğretim Programı ve Kılavuzu. MEB: Ankara.

Munby, H., Russell, T. and Martin, A. K. (2001). Teachers' knowledge and how it develops. In V. Richardson (Ed.), Handbook of research on teaching (4th ed., pp. 877904). Washington, DC: American Educational Research Association.

Nagle, L. M. and McCoy, L. P. (1999). Division of Fractions: Procedural Versus Conceptual Knowledge. In McCoy, L.P. (Ed.), Studies in Teaching:1999 Research Digest. Research Projects Presented at Annual Research Forum (Winston-Salem, NC), PP.81-85. ERIC Document Reproduction Service No:.ED 443814.

O'Hanlon, W. A. (2010). Characterizing the Pedagogical Content Knowledge of Preservice Secondary Mathematics Teachers. Doctoral disertation, Illinois State University, USA.

Oktaç, A. (2010). Birinci Dereceden Tek Bilinmeyenli Denklemler ile İlgili Kavram Yanılgıları. Matematiksel Zorluklar ve Çözüm Önerileri. E. Bingölbali ve M. F. Özmantar (Editörler) . (İkinci Baskı), s. 241-262. Ankara: Pegem Akademi Yayınevi.

Park, S. and Oliver, J. S. (2008). Revisiting the Conceptualisation of Pedagogical Content Knowledge (PCK): PCK as a Conceptual Tool to Understand Teachers as Professionals. Research in Science Education, 38, 261- 284.

Pope, S. and Sharma, R. (2001). Symbol sense: Teacher's and student's understanding. Proceedings of the British Society for Research into Learning Mathematics, 21(3), 64-69. http://www.bsrlm.org.uk/IPs/ip213/BSRLM-IP-21-3-12 adresinden erişilmiştir.

Reynolds, M. C. (Ed.). (1989). Knowledge base for the beginning teacher. New York: Pergamon Press.

Reynolds, J. A. (1992). What is Competent Beginning Teaching? A Review of the Literature, Review of Educational Research. 62, 1-35. 
Sert Çelik, H. ve Masal, E. (2018). 7. Sınıf Öğrencilerinin Denklem ve Eşitlik Konusundaki Öğrenmelerine Öğrenci Bileşeni Açısından Bir Bakış. Sakarya University Journal of Education, 8 (2), 168-186. DOI: 10.19126/suje.418532.

Seviş, Ş., (2008). The Effects of a Mathematics Teaching Methods Course On Pre-Service Elementary Mathematics Teachers' Content Knowledge for Teaching Mathematics, Yayımlanmamış yüksek lisans tezi, Orta Doğu Teknik Üniversitesi, Sosyal Bilimler Enstitüsü.

Sherin, M. G. (1996). The nature and dynamics of teachers' content knowledge. Unpublished doctoral dissertation, University of California, Berkeley.

Shulman, L. S. (1986). Those Who Understand; Knowledge Growth in Teaching. Educational Researcher, 15(2), 4-14.

Shulman, L. S. (1987). Knowledge and Teaching: Foundations of the New Reform, Harvard Educational Review, 57(1), 1-22.

Stacey, K. and MacGregor, M. (1997). Ideas About Symbolism That Students Bring to Algebra. The Mathematics Teacher, 90(2), 110-113.

Şahin, Ö., Gökkurt, B., Başıbüyük, K., Erdem, E., Nergiz, T. ve Soylu, Y. (2013). Matematik ve Sınıf Öğretmeni Adaylarının Pedagojik Alan Bilgilerinin Karşılaştırılması. The Journal of Academic Social Science Studies, 6(4), 693-713.

Şahin, Ö., Erdem, E., Başıbüyük, K., Gökkurt, B. ve Soylu, Y. (2014). Ortaokul Matematik Öğretmenlerinin Sayılarla İlgili Pedagojik Alan Bilgilerinin Gelişiminin İncelenmesi. Türk Bilgisayar ve Matematik Eğitimi Dergisi, 5(3), 207-230.

Tamir, P. (1988). Subject Matter and Related Pedagogical Knowledge in Teacher Education. Teaching and Teacher Education, 4(2), 99-110.

Tanışlı, D. ve Köse, N. Y. (2013). Pre-Service Mathematic Teachers' Knowledge of Students About the Algebraic Concepts. Australian Journal of Teacher Education, 38(2), 1-18.

Tirosh, D. (2000). Enhancing Prospective Teachers' Knowledge of Children's Conceptions: The Case of Division of Fractions. Journal for Research in Mathematics Education, $31(1), 5-25$.

Toluk-Uçar, Z. (2011). Öğretmen adaylarının pedagojik içerik bilgisi: Öğretimsel açıklamalar. Turkish Journal of Computer and Mathematics Education, 2(2), 87-102.

Türnüklü, B. E. (2005). Matematik Öğretmen Adaylarının Pedagojik Alan Bilgileri ile Matematiksel Alan Bilgileri Arasındaki İlişki. Eurasian Journal of Educational Research, 21, 234- 247. 
Yaman, H., Toluk, Z. ve Olkun, S. (2003). İlköğretim Öğrencileri Eşit İşaretini Nasıl Algılamaktadırlar? Hacettepe Üniversitesi Eğitim Fakültesi Dergisi, 24, 142- 151.

Yıldırım, A. ve Şimşek, H. (2008). Sosyal Bilimlerde Nitel Araştırma Yöntemleri (7. Baskı). Ankara: Seçkin Yayıncılık.

Yin, R. K. (2003). Case Study Research: Design and Methods (3rd ed.). Thousand Oaks, CA: Sage.

Wagner, S. (1983). What are these things called variables? The mathematics teacher, 76(7), 474-479.

Wanjala E. and Orton A. (1996). Teachers' Knowledge of Pupıls' Errors in Algebra. Proceedings of The Conference of the International Group for The Psychology of Mathematics Education, 4, 4-11. 